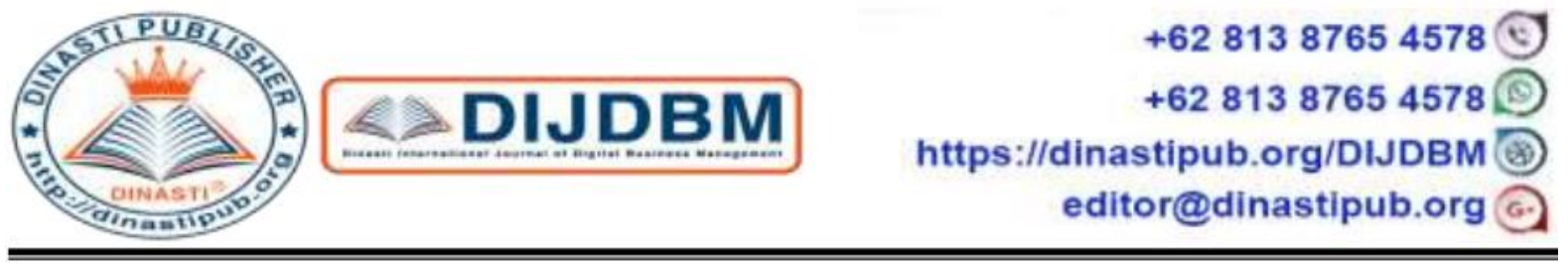

\title{
DESIGNING A PERFORMANCE APPRAISAL SYSTEM FOR MANAGEMENT CONSULTANT OFFICE "D"
}

\section{Susanto $^{1}$, Noviaty Kresna Darmasetiawan ${ }^{2}$}

1) University of Surabaya, Surabaya, Indonesia

${ }^{2)}$ University of Surabaya, Surabaya, Indonesia

\begin{tabular}{|c|c|}
\hline $\begin{array}{l}\text { ARTICLE INFORMATION } \\
\text { Received: 25rd March } 2020 \\
\text { Revised: 19th April } 2020 \\
\text { Issued: 28th April } 2020 \\
\text { Corresponding author: } \\
\text { Susanto } \\
\text { E-mail: } \\
\text { santo_xavier@yahoo.com }\end{array}$ & $\begin{array}{l}\text { Abstract: This design aims to conduct a job analysis } \\
\text { and designing a performance appraisal system for } \\
\text { Management Consultant Office "D". The } \\
\text { constructionism approach used in this design that } \\
\text { presents a structured and systematic analysis by } \\
\text { describing the steps of designing a performance } \\
\text { appraisal system through data collection methods: } \\
\text { interviews, direct observation and document analysis. } \\
\text { A summary of the findings shows that the } \\
\text { Management Consultant Office "D" has never done a } \\
\text { job analysis for each level of position in the } \\
\text { organization and don't have a performance appraisal } \\
\text { system. Therefore, a job analysis is performed for each } \\
\text { level of position and neatly formatted in the job } \\
\text { analysis table. The results of this design are in the form } \\
\text { of job analysis, determination of the performance } \\
\text { appraisal dimensions and their weighting which are } \\
\text { made into the format of the performance appraisal } \\
\text { form along with the procedures and the procedures for } \\
\text { carrying out the performance appraisal. } \\
\text { Keywords: Performance Appraisal, Performance } \\
\text { Appraisal System, Job Analysis, Graphic Rating Scale. }\end{array}$ \\
\hline
\end{tabular}

\section{INTRODUCTION}

In facing a business competition, company leaders are required to take more strategic and coherent approach in organizing and managing resources within the company, including managing human resources as the most valuable assets. Human resource management is a strategic and coherent approach so that people as the most valuable assets of the organization, both individually and collectively can contribute to the achievement of organizational goals (Armstrong, 2006). People have to do a good job, they need to know the work they have to complete and what criteria they must fulfill in order to achieve what is called effective performance. 
It was stated that even a company still does not have an human resources department, still conducts a performance appraisal process for the duties and responsibilities of its employees. It is clear that the existence of performance appraisal is very important to do even there is no human resources department and even if it is done in a very simple way. The purpose of performance appraisal is to present feedback to employees regarding their performance, facilitate salary increase decisions, and promotions, encourage performance improvement, set and measure goals, determine employee training and development needs and improve overall company performance. Therefore, choosing the right performance appraisal system relies heavily on a good understanding of what is important to the organization. (Haponava and Al-Jibouri, 2009; Grote, 2002; Arnautu and Panc, 2015; Enshassi and Shorafa, 2015).

Management consultant office " $D$ " is a management services consulting firm, IT and taxation (according to client's request) with coverage in East Java, Central Java, Bali, Kalimantan and Papua at present. The Partner feels aware that the quality of his consulting services is a major aspect that must be continuously improved and monitored to be in line with the vision "Being the Trusted and Largest Partner for Your Business". The importance of implementing performance appraisal in the management consultant office " $\mathrm{D}$ " is the results of the performance measurement will be used as a basis for client distribution. The distribution of clients should be right according to the ability of the work team. Therefore, the Partner must monitoring human resources in his office and one of the forms is by having a performance appraisal system design. The purpose of this design is to conduct a job analysis which consist a job description, job specifications, and job performance standards for each level of position per department and design a performance appraisal system.

\section{LITERATURE REVIEW \\ Performance Appraisal}

The essence of performance appraisal as part of human resource management activities is the process by which individual performance is assessed and evaluated. Nothing is more risky for a supervisor than to assess the performance of subordinates. Dessler (2015) states that performance appraisal means evaluating employee performance in the present or past relative to its performance standards. According to Moon (1994), performance appraisal is a formally documented system for periodically reviewing individual performance.

The reason and purpose of the need for performance appraisal according to Dessler (2015) and Cascio (2016) is that performance appraisal provides the basis for payroll, promotion, and retention decisions; evaluating employee performance to ensure that each employee's performance is in line with the company's overall goals; develop plans to correct deficiencies; provide an opportunity to review employee career plans; and identify the need for training and the necessary corrective actions.

\section{Performance Appraisal System}

The graphic rating scale method is a scale method that writes a number of dimensions of work such as communication, teamwork, and range of performance values for each dimension of work. Employees are assessed by identifying the value that best matches their level of performance for each dimension. According to Idowu (2017), the graphic rating scale 
method is the most widely used method in most organizations that conduct performance appraisals. The graphical scale method requires a list of performance appraisals and with that list, assessors assess employee performance based on a scale that ranges from poor to very good according to the aspect being evaluated.

Graphic rating scale is also suitable to be applied in various types of work with minimal costs, simple effort and short time. But on the other hand, grading by this method can be subjective and it is difficult to achieve consistency between the ratings given by different assessors. Even objectivity is achieved, formulating the results of performance appraisals with a single rating is considered excessive in making possible simplifications in the performance appraisal process, an incorrectly and arbitrarily appraisal which can have an impact on the performance appraisal results which actually demotivate employees. There are several types of rating scales that can be used as described by Armstrong (2015). In performance appraisal, a graphical scale can be defined by alphabet (a, b, c) or by numeric (1, 2,3 ) which is then described as a/ 1 is very good, b/2 is good, c/3 is bad and d/4 is very bad.

Cascio (2016) explained that in compiling a performance appraisal system, basically requires a job analysis which can then be formulated into job performance standards. So, that employee performance appraisal can be carried out. Steps that should be taken when developing a performance appraisal system:

The first step, conducting a job analysis to determine the characteristics needed to achieve good job performance. Job analysis is a process of gathering, analyzing and determining work-related information. Job analysis produces information to compile job descriptions, job specifications and job performance standards (Armstrong, 2014; Dessler, 2015; Cascio, 2016).

The second step, Incorporating the characteristics of the job analysis into the assessment instruments. Regardless of the method used, give all appraisers a written standard. In this design, the preparation of assessment instruments uses a result approach with a reference to the job performance standards that have been prepared in the job analysis process. Results approach is an appraisal approach that is oriented/focuses on employee performance results without considering the nature of the employee or how the employee completes his work. This approach requires a shorter time and relatively low cost than defining and measuring the behavior needed to achieve certain performance (Aguinis, 2013).

The third step, provide and socialize written instructions. Explain to the assessor to use the appraisal instrument properly. A performance appraisal form is useful for gathering information related to employee performance both in the form of hardcopy and electronically. The performance appraisal form is adjusted to the assessment approach adopted by the organization. There are no standard forms of assessment in various types of organizations. Due to the absence of these standard forms, Aguinis (2013) describes some basic characteristics that are minimally contained in the performance appraisal forms, so that performance appraisals can be effective that is simplicity, relevancy, descriptiveness, adaptability, comprehensiveness, definitional clarity, communication and time orientation.

The fourth step, establish a system to detect potential discriminatory effects or misappropriation of the performance appraisal process. In Armstrong (2015), it is mentioned 
how to achieve consistency in conducting performance appraisal by conducting training, the purpose of training is to teach managers how to match ranking with performance and ensure that managers understand the definition of each level of ranking in performance appraisal and provide guidance and practice how to use performance appraisal tools; peer reviews, managers meet to review the pattern of each rating and further review conflicting decisions/unusual judgments; and monitoring, the performance appraisal process is monitored by the central department, usually the human resources department that opposes unusual assessment patterns, identifies and questions suspicious appraisals.

The fifth step, include a formal appeals mechanism, plus further review related to the results of the assessment that has been carried out. Documentation the judgment and reason for each decision. Armstrong (2015) explains the steps to make further reviews related to performance appraisal that is preparing, working on a clear structure, creating a good atmosphere, providing good feedback, using time well, using praise, letting employees do most of the conversation, giving employees the opportunity to evaluate themselves, discuss performance not personality, conduct performance analysis, do not deliver unplanned criticism and approve further actions.

The sixth step, provide performance counseling or corrective guidance for people who are bad performer. Managing people who are bad performer must be a positive process based on feedback and looking forward to what can be improved, the most important thing is how their superiors can provide support and assistance to improve their performance. Armstrong (2015) provides guidance in taking corrective actions for people who are bad performer starting with identifying and agreeing to the bad performance, determining the reasons behind the bad performance, determining and approving the actions needed, providing support for the actions needed, monitoring and providing feedback.

\section{RESEARCH METHODS}

The designer uses a constructionism approach in this design. The constructionism approach is a structured and systematic analysis of the actions of a group by making good and detailed observations to understand how the actors in the group create their social world. The main characteristics of this approach are the involvement and in-depth analysis by the designer to the actors by direct contact, using theoretical studies as a basis and initial information in carrying out further designs so that at the end of the design, the designer is able to obtain a finding and the results of the design through the process that has been carried out in accordance with the data and experience of actors in accordance with the steps of designing a performance appraisal system that refers to the Cascio literature (Sekaran and Bougie, 2016).

Data collection methods used were interviews, observation and document analysis. Data collection by means of interviews is intended to obtain data on a general description of business entities, interactions related to the human resources involved, demands for performance on duties and responsibilities, demands from external parties who use the services of the management consultant office " $D$ ". This interview will be conducted on partners, managers, supervisors, juniors, support staff and clients of the management consultant office " $\mathrm{D}$ ". 
Table 1.1 Interview Method

\begin{tabular}{|c|c|c|c|c|c|}
\hline $\begin{array}{l}\text { Participant } \\
\text { status }\end{array}$ & $\begin{array}{c}\text { Number } \\
\text { of } \\
\text { participant }\end{array}$ & $\begin{array}{l}\text { Number } \\
\text { of hour }\end{array}$ & $\begin{array}{l}\text { Interview } \\
\text { criteria }\end{array}$ & Interview topic & $\begin{array}{c}\text { Information to be } \\
\text { obtained }\end{array}$ \\
\hline Partner & 1 & 10 & $\begin{array}{l}\text { 1. Understand } \\
\text { the history of } \\
\text { the company } \\
\text { 2. Understand } \\
\text { the human } \\
\text { resources of } \\
\text { the company } \\
\text { 3. Understand } \\
\text { the importance } \\
\text { of } \\
\text { performance } \\
\text { appraisal }\end{array}$ & $\begin{array}{l}\text { 1.Company } \\
\text { history, work } \\
\text { barriers } \\
\text { 2.Employee } \\
\text { performance } \\
\text { 3.Performance } \\
\text { appraisal that } \\
\text { have been } \\
\text { applied }\end{array}$ & $\begin{array}{l}\text { 1. Main task and } \\
\text { daily routines } \\
\text { 2. Workflow and } \\
\text { employee } \\
\text { responsibilities } \\
\text { 3. The expected } \\
\text { performance of } \\
\text { employees } \\
\text { 4. The expected of } \\
\text { performance } \\
\text { appraisal system }\end{array}$ \\
\hline Manager & 2 & 6 & $\begin{array}{l}\text { 1. Has worked } \\
>8 \text { years in } \\
\text { management } \\
\text { consultant } \\
\text { office "D" }\end{array}$ & $\begin{array}{l}\text { 1. Team working } \\
\text { experience } \\
\text { 2. Work } \\
\text { environment } \\
\text { 3. Subordinate } \\
\text { performance } \\
\text { appraisal } \\
\text { 4. Interaction } \\
\text { with } \\
\text { subordinate }\end{array}$ & $\begin{array}{l}\text { 1. Main task and } \\
\text { daily routines } \\
\text { 2. Subordinate } \\
\text { specifications } \\
\text { that can support } \\
\text { team work } \\
\text { 3. Expected } \\
\text { subordinate's } \\
\text { performance } \\
\text { 4. Workflow and } \\
\text { responsibilities } \\
\text { 5. Communication } \\
\text { and team work }\end{array}$ \\
\hline Supervisor & 2 & 4 & $\begin{array}{l}\text { 1. Has worked } \\
>5 \text { years in } \\
\text { management } \\
\text { consultant } \\
\text { office "D" }\end{array}$ & $\begin{array}{l}\text { 1. Team working } \\
\text { experience } \\
\text { 2. Work } \\
\text { environment } \\
\text { 3. Subordinate } \\
\text { performance } \\
\text { appraisal } \\
\text { 4. Interaction } \\
\text { with } \\
\text { subordinate }\end{array}$ & $\begin{array}{l}\text { 1. Main task and } \\
\text { daily routines } \\
\text { 2. Subordinate } \\
\text { specifications } \\
\text { that can support } \\
\text { team work } \\
\text { 3. Expected } \\
\text { subordinate's } \\
\text { performance } \\
\text { 4. Workflow and } \\
\text { responsibilities } \\
\text { 5. Communication } \\
\text { and team work }\end{array}$ \\
\hline Junior & 2 & 4 & $\begin{array}{l}\text { 1. Has worked } \\
\text { >3 years in } \\
\text { management } \\
\text { consultant } \\
\text { office "D" }\end{array}$ & $\begin{array}{ll}\text { 1. } & \text { Team } \\
& \text { working } \\
\text { experience } \\
\text { 2. Work } \\
\text { environment } \\
\text { 3. } \\
\text { Interaction }\end{array}$ & $\begin{array}{l}\text { 1. Main task and } \\
\text { daily routines } \\
\text { 2. Subordinate } \\
\text { specifications } \\
\text { that can support } \\
\text { team work }\end{array}$ \\
\hline
\end{tabular}




\begin{tabular}{|c|c|c|c|c|c|}
\hline & & & & $\begin{array}{l}\text { with } \\
\text { immediate } \\
\text { supervisor }\end{array}$ & $\begin{array}{l}\text { 3. Expected } \\
\text { subordinate's } \\
\text { performance } \\
\text { 4. Workflow and } \\
\text { responsibilities } \\
\text { 5. Communication } \\
\text { and team work }\end{array}$ \\
\hline $\begin{array}{c}\text { Supporting } \\
\text { staff }\end{array}$ & 5 & 5 & $\begin{array}{l}\text { 1. Has worked } \\
>1 \text { years in } \\
\text { management } \\
\text { consultant } \\
\text { office "D" }\end{array}$ & \begin{tabular}{|ll} 
1. & Team \\
& working \\
& experience \\
2. & Work \\
& environment \\
3. & Interaction \\
& with peers
\end{tabular} & $\begin{array}{l}\text { 1. Main task and } \\
\text { daily routines } \\
\text { 2. Communication } \\
\text { and team work } \\
\text { 3. Workflow and } \\
\text { responsibilities }\end{array}$ \\
\hline Client & 2 & 4 & $\begin{array}{l}\text { 1. Joined in } \\
\text { management } \\
\text { consultant } \\
\text { office "D" }>3 \\
\text { years }\end{array}$ & $\begin{array}{l}\text { 1. Experience } \\
\text { when joined } \\
\text { with } \\
\text { management } \\
\text { consultant } \\
\text { office "D" } \\
\text { 2. Responses to } \\
\text { the } \\
\text { management } \\
\text { consultant } \\
\text { office "D" } \\
\text { team work } \\
\text { 3. Complaints } \\
\text { regarding the } \\
\text { management } \\
\text { consultant } \\
\text { office "D" } \\
\text { team work }\end{array}$ & $\begin{array}{l}\text { 1. The } \\
\text { performance } \\
\text { of consultant } \\
\text { team when the } \\
\text { client's visit } \\
\text { 2. The attitudes } \\
\text { and behavior } \\
\text { of individuals } \\
\text { in the team } \\
\text { work } \\
\text { 3. The result of } \\
\text { work from the } \\
\text { consultant } \\
\text { team } \\
\text { 4. Benefits joined } \\
\text { with } \\
\text { management } \\
\text { consultant } \\
\text { office "D" }\end{array}$ \\
\hline Total & 14 & 33 & & & \\
\hline
\end{tabular}

Observations method are made to obtain data through operational activities in the management consultant office "D" such as the information of workflow, reporting, documentation, employee attitudes and interaction between employees. Observations at the client's office of management consultant " $\mathrm{D}$ " are made to obtain data about the consultant team performance when visiting, knowledge and ability of the consultant team to solve problems and interaction with the client.

Table 1.2 Observation Method

\begin{tabular}{|c|c|c|l|}
\hline Activities & $\begin{array}{c}\text { Number of } \\
\text { hour }\end{array}$ & \multicolumn{1}{|c|}{ Focus of observation } & Information to be obtained \\
\hline Operational activities & 30 & 1. Culture and work & 1. Workflow \\
\hline
\end{tabular}




\begin{tabular}{|c|c|c|c|}
\hline $\begin{array}{l}\text { in the management } \\
\text { consultant office "D" }\end{array}$ & & $\begin{array}{l}\text { environment } \\
\text { 2. Compliance with } \\
\text { regulations } \\
\text { 3. Employee attitudes and } \\
\text { behavior } \\
\text { 4. Interaction between } \\
\text { employees } \\
\text { 5. Interaction between } \\
\text { teams } \\
\text { 6. Interaction of } \\
\text { supervisor and } \\
\text { subordinates }\end{array}$ & $\begin{array}{l}\text { 2. Reporting flow and } \\
\text { responsibilities } \\
\text { 3. Documentation of work } \\
\text { result } \\
\text { 4. Employee attitudes and } \\
\text { behavior } \\
\text { 5. Interaction between } \\
\text { employees } \\
\text { 6. Interaction between } \\
\text { teams } \\
\text { 7. Interaction of } \\
\text { supervisor and } \\
\text { subordinates }\end{array}$ \\
\hline $\begin{array}{l}\text { Visiting and observing } \\
\text { the work process of } \\
\text { the consultant team at } \\
\text { the management } \\
\text { consultant "D" } \\
\text { client's office }\end{array}$ & 10 & $\begin{array}{l}\text { 1. Culture and work } \\
\text { environment } \\
\text { 2. The consultant team } \\
\text { attitudes and behavior } \\
\text { when visiting client } \\
\text { 3. Interaction between } \\
\text { client's employee and } \\
\text { consultant team } \\
\text { 4. Interaction between } \\
\text { consultant team and } \\
\text { client } \\
\text { 5. The problem solving } \\
\text { from consultant team } \\
\text { 6. Client responses to } \\
\text { consultant team }\end{array}$ & $\begin{array}{l}\text { 1. The consultant team } \\
\text { attitudes and behavior } \\
\text { when visiting client's } \\
\text { 2. Interaction between } \\
\text { client's employee and } \\
\text { consultant team } \\
\text { 3. Interaction between } \\
\text { consultant team and } \\
\text { client } \\
\text { 4. Knowledge and ability } \\
\text { of the consultant team } \\
\text { to solve problems }\end{array}$ \\
\hline Total & 40 & & \\
\hline
\end{tabular}

Document analysis is carried out to obtain data through organizational chart and structure related to decision making, communication and reporting flow. Job description and specification related to duties, responsibilities and minimum specification of each employee in the Office of Management Consultant "D".

Table 1.3 Document Analysis Method

\begin{tabular}{|c|c|c|c|}
\hline Document & Focus of analysis & Category & Information to be obtained \\
\hline $\begin{array}{l}\text { Chart and } \\
\text { structure of the } \\
\text { organization }\end{array}$ & $\begin{array}{l}\text { 1. Decision making flow } \\
\text { 2. Communication flow } \\
\text { 3. Reporting flow and } \\
\text { responsibilities }\end{array}$ & Internal & $\begin{array}{l}\text { 1. Decision making } \\
\text { 2. Communication flow of } \\
\text { each level of position } \\
\text { per department } \\
\text { 3. Reporting and } \\
\text { responsibilities }\end{array}$ \\
\hline Job Description & $\begin{array}{l}\text { 1. Scope of work and } \\
\text { responsibilities }\end{array}$ & Internal & $\begin{array}{l}\text { 1. Duties and } \\
\text { responsibilities of each } \\
\text { level of position per } \\
\text { department }\end{array}$ \\
\hline
\end{tabular}




\begin{tabular}{|c|c|c|c|}
\hline $\begin{array}{c}\text { Job } \\
\text { Specification }\end{array}$ & $\begin{array}{c}\text { 1. Specification needed to } \\
\text { support the existing work }\end{array}$ & Internal & $\begin{array}{l}\text { 1. Specification needed to } \\
\text { fulfill the duties and } \\
\text { responsibilities }\end{array}$ \\
\hline
\end{tabular}

\section{FINDINGS AND DISCUSSION}

In designing a performance appraisal system, the first step is to conduct a job analysis consisting of job descriptions that refer to the Armstrong (2014) literature, job specifications that refer to the Dessler (2015) and Armstrong (2014) literature and job performance standards that refer to the Cascio (2016) literature. The following is the format of the job analysis which includes a job description, job specifications and job performance standards for each level of the management consultant office "D":

Table 1.4 Job Analysis Form for Management Consultant Office "D"

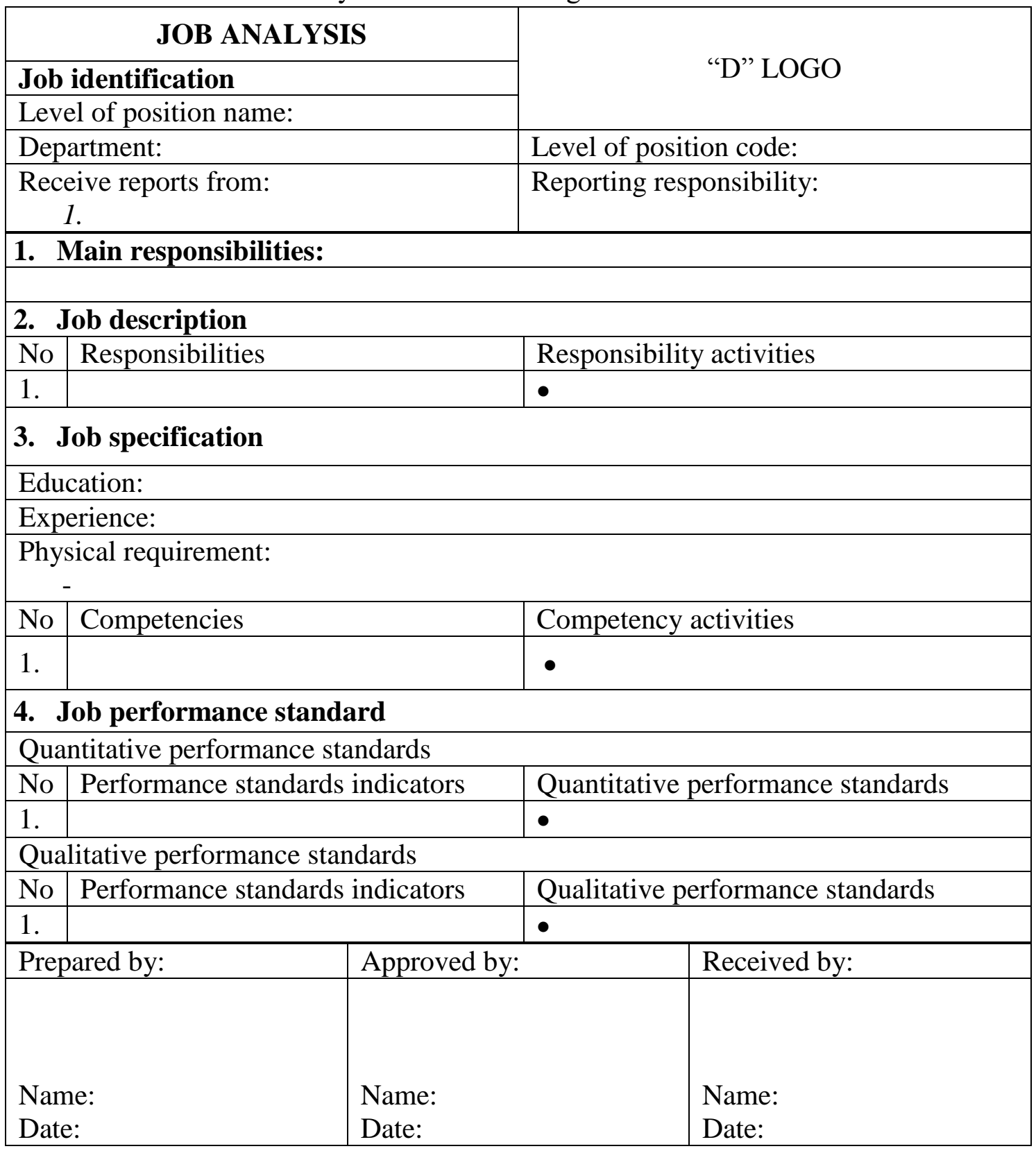


The compilation of the instruments of performance appraisal refers to the Aguinis (2013) literature related to the result approach and the Cascio (2016) literature which consist some of the requirements for a performance appraisal system to run effectively. Table 1.5 shows the instruments of performance appraisal and its weighting for each level of position per department in the management consultant office "D", which will be used in the performance appraisal form. From the instrument of performance appraisal there are three appraisal categories: attitudes and behaviors; technical; and non technical. From these categories are consist of fifteen appraisal instrument. Supporting staff have a total of 9 instruments to be assessed, junior consultants have a total of 10 instruments to be assessed, supervisor consultants have a total of 11 instruments to be assessed, manager consultants have a total of 12 instruments to be assessed and partners have a total of 11 instruments to be assessed.

Table 1.5 Instruments of Performance Appraisal for Management Consultant Office "D"

\begin{tabular}{|c|c|c|c|c|c|c|}
\hline \multirow{2}{*}{ No. } & \multirow[b]{2}{*}{ Instrument } & \multicolumn{5}{|c|}{ Level of position } \\
\hline & & $\begin{array}{c}\text { Supporting } \\
\text { staff }\end{array}$ & $\begin{array}{c}\text { Junior } \\
\text { consultant }\end{array}$ & $\begin{array}{c}\text { Supervisor } \\
\text { consultant }\end{array}$ & $\begin{array}{l}\text { Manager } \\
\text { consultant }\end{array}$ & Partner \\
\hline \multicolumn{7}{|c|}{ Attitudes and behaviors } \\
\hline 1. & Communication & $5 \%$ & $10 \%$ & $10 \%$ & $10 \%$ & $10 \%$ \\
\hline 2. & Loyalty & $5 \%$ & $5 \%$ & $5 \%$ & $5 \%$ & $5 \%$ \\
\hline 3. & Responsibility & $10 \%$ & $5 \%$ & $5 \%$ & $5 \%$ & $5 \%$ \\
\hline 4. & Discipline & $10 \%$ & $5 \%$ & $5 \%$ & $5 \%$ & $5 \%$ \\
\hline 5. & Teamwork & $5 \%$ & $10 \%$ & $10 \%$ & $10 \%$ & $5 \%$ \\
\hline \multicolumn{2}{|c|}{ Total } & $35 \%$ & $35 \%$ & $35 \%$ & $35 \%$ & $30 \%$ \\
\hline \multicolumn{7}{|c|}{ Technical } \\
\hline 6. & $\begin{array}{l}\text { Skills and } \\
\text { accuracy of } \\
\text { preparing } \\
\text { reports/programs }\end{array}$ & $5 \%$ & $30 \%$ & $25 \%$ & $10 \%$ & - \\
\hline 7. & Documentation & $5 \%$ & $15 \%$ & - & - & - \\
\hline 8. & $\begin{array}{l}\text { Knowledge and } \\
\text { practice }\end{array}$ & - & $10 \%$ & $15 \%$ & $20 \%$ & $10 \%$ \\
\hline 9. & $\begin{array}{l}\text { Operational } \\
\text { technical work }\end{array}$ & $35 \%$ & - & - & - & - \\
\hline 10. & $\begin{array}{l}\text { Management of } \\
\text { facilities and } \\
\text { infrastructure }\end{array}$ & $20 \%$ & - & - & - & - \\
\hline \multicolumn{2}{|c|}{ Total } & $65 \%$ & $55 \%$ & $40 \%$ & $30 \%$ & $10 \%$ \\
\hline \multicolumn{7}{|c|}{ Non Technical } \\
\hline 11. & $\begin{array}{l}\text { Organization } \\
\text { development }\end{array}$ & - & - & - & $5 \%$ & $10 \%$ \\
\hline 12. & Analytical skills & - & - & $10 \%$ & $10 \%$ & $10 \%$ \\
\hline 13. & $\begin{array}{l}\text { Soft skill and } \\
\text { relation }\end{array}$ & - & $5 \%$ & $5 \%$ & $10 \%$ & $20 \%$ \\
\hline 14. & $\begin{array}{l}\text { Planning and } \\
\text { delegation }\end{array}$ & - & $5 \%$ & $5 \%$ & $5 \%$ & $10 \%$ \\
\hline
\end{tabular}




\begin{tabular}{|c|c|c|c|c|c|c|}
\hline 15. & $\begin{array}{l}\text { Decision making } \\
\text { and problems } \\
\text { solving }\end{array}$ & - & - & $5 \%$ & $5 \%$ & $10 \%$ \\
\hline \multicolumn{2}{|c|}{ Total } & - & $10 \%$ & $25 \%$ & $35 \%$ & $60 \%$ \\
\hline \multicolumn{2}{|c|}{ Grand total } & $100 \%$ & $100 \%$ & $100 \%$ & $100 \%$ & $100 \%$ \\
\hline
\end{tabular}

The performance appraisal form was designed based on a theoretical study by Aguinis (2013), aspects of acceptability and practicality by Cascio (2016) and a graphic rating scale method by Idowu (2017) and Armstrong (2015) which was then adjusted to the needs of the management consultant office " $\mathrm{D}$ ". The following is the performance appraisal form for the management consultant office "D":
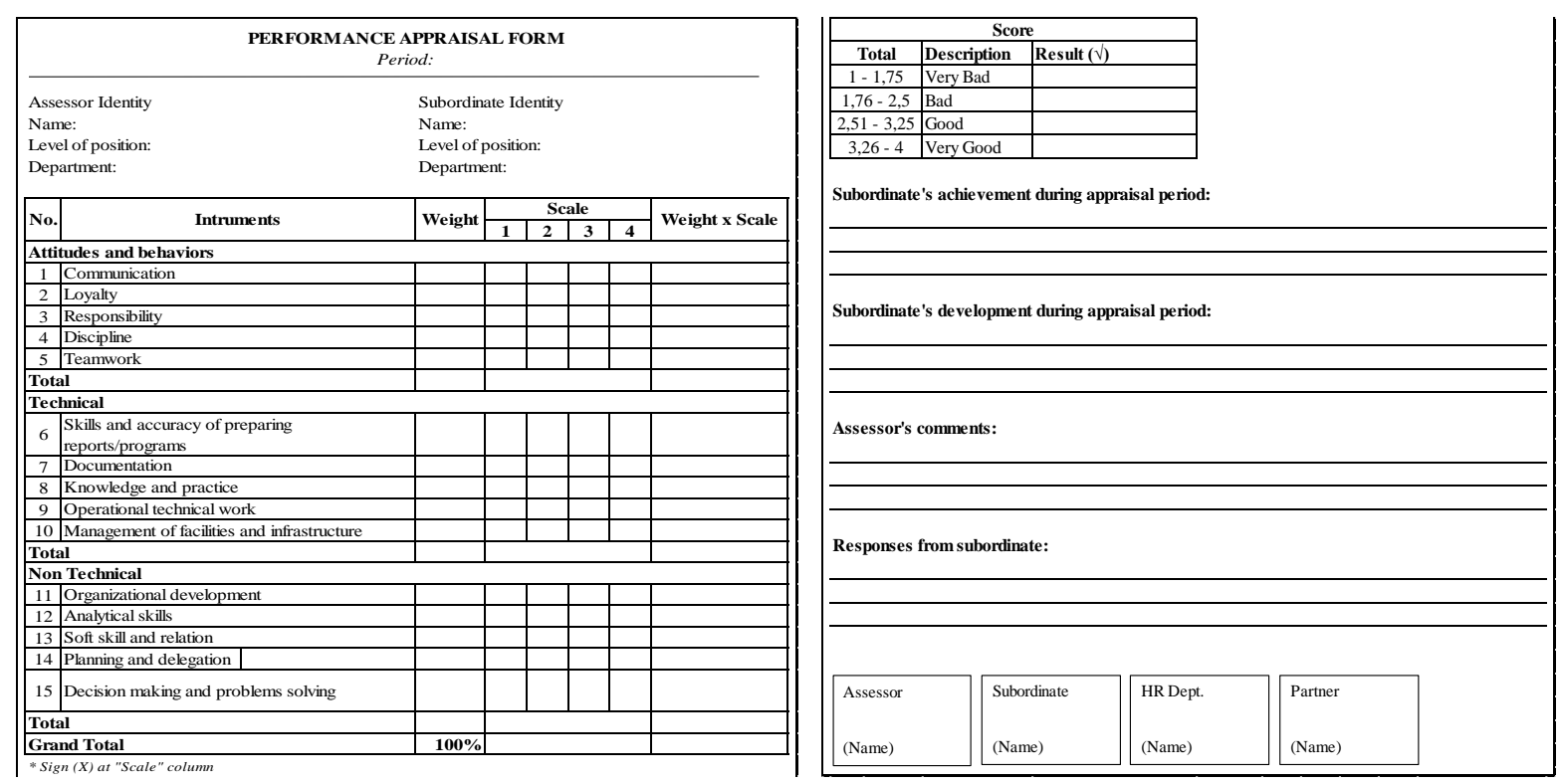

Picture 1.1 Performance Appraisal Form for Management Consultant Office "D”

The performance appraisal form is completed with appraisal procedures that refer to the appraisal process component by Keeping and Levy (2000) literature. The procedure for appraisal provides an explanation to the assessor briefly and clearly how to give scale to each of the existing assessment instruments. The procedure of appraisal explains the evaluation standard of each instrument in accordance with the existing level of position. Equipped with appraisal procedures, the assessor is expected to be able to provide an appraisal in accordance with actual conditions and minimize bias during the performance appraisal process. The following are the procedures for performance appraisal for management consultant office "D":

Table 1.6 The Procedures for Performance Appraisal for Management Consultant Office "D"

\begin{tabular}{|c|c|l|}
\hline No. & \multicolumn{1}{|c|}{ Instruments } & \multicolumn{1}{c|}{ Appraisal Indicators } \\
\hline \multicolumn{2}{|c|}{ Attitudes and behaviors } & $(4)$ \\
\hline \multirow{4}{*}{1.} & \multirow{2}{*}{ Communication } & $(3)$ \\
\cline { 3 - 3 } & & $(2)$ \\
\cline { 3 - 3 } & & $(1)$ \\
\hline
\end{tabular}




\begin{tabular}{|c|c|c|}
\hline \multirow{4}{*}{2.} & \multirow{4}{*}{ Loyalty } & (4) \\
\hline & & (3) \\
\hline & & (2) \\
\hline & & (1) \\
\hline \multirow{4}{*}{3.} & \multirow{4}{*}{ Responsibility } & (4) \\
\hline & & (3) \\
\hline & & (2) \\
\hline & & (1) \\
\hline \multirow{4}{*}{4.} & \multirow{4}{*}{ Discipline } & (4) \\
\hline & & (3) \\
\hline & & (2) \\
\hline & & (1) \\
\hline \multirow{4}{*}{5.} & \multirow{4}{*}{ Teamwork } & (4) \\
\hline & & (3) \\
\hline & & (2) \\
\hline & & (1) \\
\hline \multicolumn{3}{|c|}{ Technical } \\
\hline \multirow{4}{*}{6.} & \multirow{4}{*}{$\begin{array}{l}\text { Skill and accuracy of } \\
\text { preparing reports/programs }\end{array}$} & (4) \\
\hline & & (3) \\
\hline & & (2) \\
\hline & & (1) \\
\hline \multirow{4}{*}{7.} & \multirow{4}{*}{ Documentation } & (4) \\
\hline & & (3) \\
\hline & & (2) \\
\hline & & (1) \\
\hline \multirow{4}{*}{8.} & \multirow{4}{*}{ Knowledge and practice } & (4) \\
\hline & & (3) \\
\hline & & (2) \\
\hline & & (1) \\
\hline \multirow{4}{*}{9.} & \multirow{4}{*}{ Operational technical work } & (4) \\
\hline & & (3) \\
\hline & & (2) \\
\hline & & (1) \\
\hline \multirow{4}{*}{10.} & \multirow{4}{*}{$\begin{array}{l}\text { Management of facilities and } \\
\text { infrastructure }\end{array}$} & (4) \\
\hline & & (3) \\
\hline & & (2) \\
\hline & & (1) \\
\hline \multicolumn{3}{|c|}{ Non Technical } \\
\hline \multirow{4}{*}{11.} & \multirow{4}{*}{ Organization development } & (4) \\
\hline & & (3) \\
\hline & & (2) \\
\hline & & (1) \\
\hline \multirow{4}{*}{12.} & \multirow{4}{*}{ Analytical skills } & (4) \\
\hline & & (3) \\
\hline & & (2) \\
\hline & & (1) \\
\hline 13. & Soft skill and relation & (4) \\
\hline
\end{tabular}




\begin{tabular}{|l|l|l|}
\hline \multirow{4}{*}{14.} & $(3)$ \\
\cline { 3 - 3 } & \multirow{4}{*}{ Planning and delegation } & $(2)$ \\
\cline { 3 - 3 } & & $(1)$ \\
\hline \multirow{4}{*}{15.} & $\begin{array}{l}\text { Decision making and } \\
\text { problems solving }\end{array}$ & $(3)$ \\
\cline { 3 - 3 } & & $(2)$ \\
\cline { 3 - 3 } & & $(1)$ \\
\cline { 3 - 3 } & & $(4)$ \\
\hline
\end{tabular}

Procedures for conducting performance appraisals are prepared in accordance with the needs of the management consultant office " $\mathrm{D}$ " and refer to the main components of a performance appraisal system by Keeping and Levy (2000), namely "the appraisal process" where a performance appraisal system must have clear and directed guidelines related to policies and the assessment procedures used to be implemented during the performance appraisal process. The following are the proposed procedures for carrying out performance appraisals for the management consultant office " $\mathrm{D}$ ":
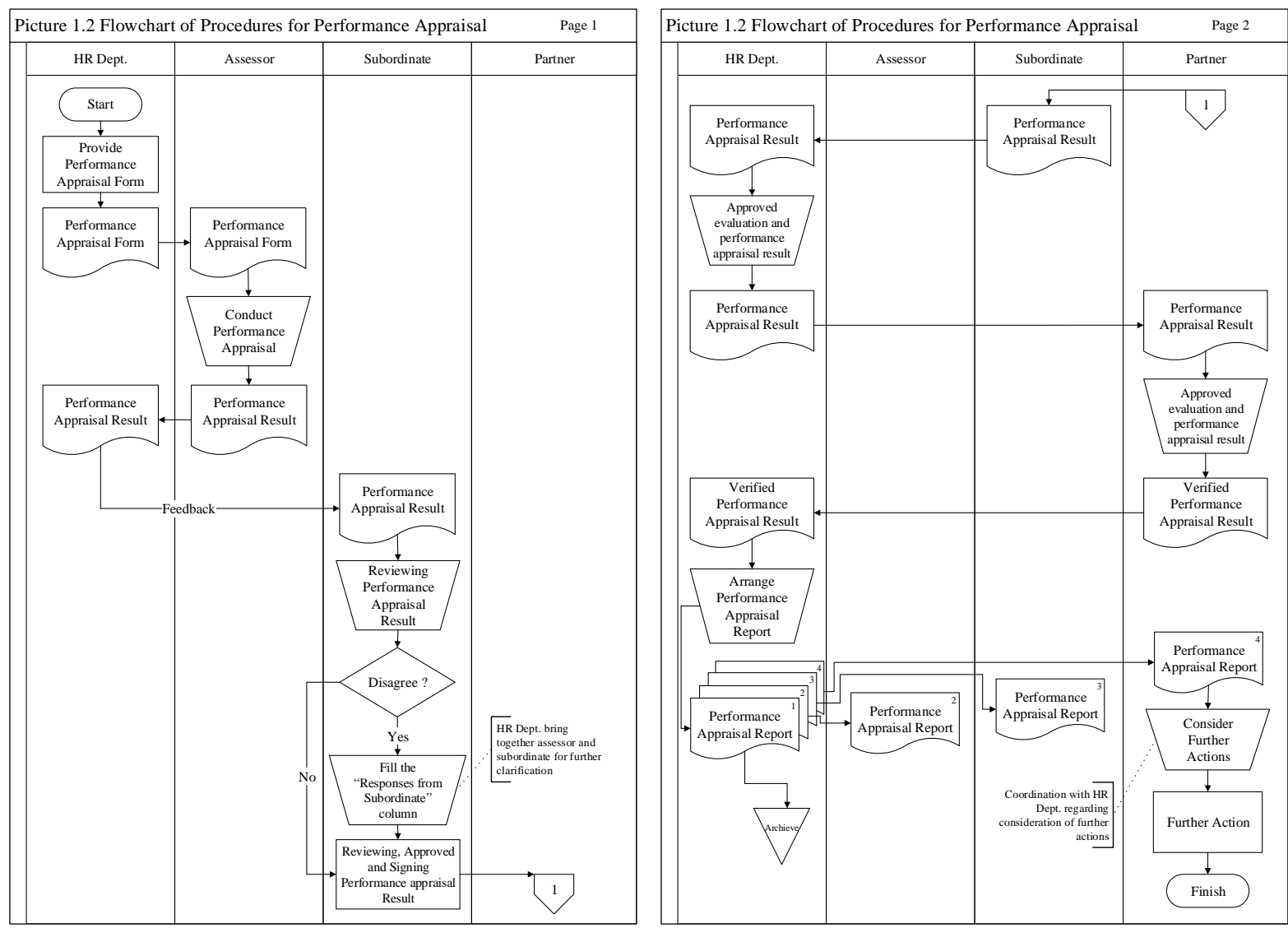

Picture 1.2 Flowchart of Procedures for Performance Appraisal for Management Consultant Office "D" 


\section{CONCLUSION AND SUGESTION}

The job description of management consultant office " $\mathrm{D}$ " is only written in a simple form of responsibilities and specifications for the level of partners, managers, supervisors and juniors arranged in the annual meeting at Villa Arca, Trawas on 1-3 November 2013. Until 2019 there is no improvements and updates have been made in the job description, job specifications and job performance standards for each level of position per department. Partner of management consultant office "D" requires a basis in dividing clients into work teams based on the performance appraisal, but still do not have a performance appraisal system and never assess employees performance's. Therefore, a job analysis which consists job description, job specifications and job performance standards for each level of position per department is carried out and designs a performance appraisal system for the management consultant office " $\mathrm{D}$ ".

The most important step to the success of the performance appraisal system in management consultant office "D" is the establishment of human resources department to actually implement the performance appraisal system that has been designed. Partners and the human resources department need to provide understanding of the implementation of the performance appraisal system to all employees that the performance appraisal is to achieving the organization's mission, as a basis for payment, promotion and retention decisions, as a reference for validating employee performance, helping to identify personality development needs and employee careers, identifying organizational development and other goals.

It is suggested that performance appraisals are conducted once every six months with the consideration that once a year there will be bias in performance appraisals and once in three months are inefficient and ineffective due to the time of appraisal being too close. Each assessor need to make daily work records related to the work of employees. When conducting performance appraisals, assessor can reopen the records related to employee performance to be assessed or clarifying of performance appraisal results from other assessor. If possible, relevant evidence can be collected.

\section{REFERENCE}

Aguinis, H. 2013. Performance Management, $3^{\text {rd }}$ Edition. United States:Pearson Education, Inc.

Armstrong, M. 2006. Performance Management, Key Strategies and Practical Guidelines, $3^{\text {rd }}$ edition. London:Kogan Page Limited.

Armstrong, M.. 2014. Armstrong's Handbook of Human Resource Management Practice, $13^{\text {th }}$ edition. London:Kogan Page Limited.

Armstrong, M. 2015. Armstrong's Handbook of Performance Management, $5^{\text {th }}$ edition. United Kongdom:Kogan Page Limited.

Arnautu, E., and Panc, I. 2015. "Evaluation Criteria for Performance Appraisal of Faculty Members". Procedia - Social and Behavioral Sciences. Vol. 203: 386 - 392.

Cascio, W.F. 2016. Managing Human Resources: Productivity, Quality of Work Life, Profits, $10^{\text {th }}$ edition. New York:McGraw-Hill Education. 
Dessler, G. 2015. Manajemen Sumber Daya Manusia: Human Resource Management. Jakarta:Salemba Empat.

Enshassi, A. A., and Shorafa, F. E. 2015. "Key Performance Indicators for The Maintenance of Public Hospitals Buildings in The Gaza Strip". Facilities. Vol. 33 Issue: 3/4, pp.206228.

Grote, R. C. 2002. The Performance Appraisal Questions and Answer Book: A Survival Guide for Managers. New York:American Management Association.

Haponava, T., and Al-Jibouri, S. 2009. "Identifying Key Performance Indicators for Use in Control of Preproject Stage Process in Construction". International Journal of Productivity and Performance Management. Vol. 58 Issue: 2, pp.160-173.

Idowu, A.O. 2017 "Effectiveness of Performance Appraisal System and Its Effect on Employee Motivation". Nile Journal of Business and Economics. Vol. 5, pp.15-39.

Keeping, L., and Levy, P.E. 2000 "Performance Appraisal Reactions: Measurement, Modeling and Method Bias". Journal of Applied Psychology. Vol. 85, No. 5, pp.708-723.

Moon, P. 1994. Penilaian Karyawan: Sistem Penilaian yang Efektif untuk Mendapatkan Kinerja Terbaik. Jakarta:Pustaka Binaman Pressindo.

Sekaran, U., and Bougie, R. 2016. Research Methods for Business: A Skill Building Approach, $7^{\text {th }}$ Edition. United Kingdom:John Wiley \& Sons. 